\title{
Neural Network Prediction of Performance Parameters of an Inclined Plate Seed Metering Mechanism and its Reverse Mapping for Rice
}

\author{
Manisha Sahu* and Ajay Verma \\ Department of Farm Machinery and Power Engineering, IGKV University, \\ Raipur 492012 (Chhattisgarh), India \\ *Corresponding author
}

\section{Keywords}

Neural network prediction,

Performance,

Inclined plate seed,

Metering

mechanism

Reverse Mapping for RICE

\section{Article Info}

Accepted:

24 September 2018

Available Online:

10 October 2018

\section{A B S T R A C T}

India is a predominantly agriculture based economy country. Annual population growth rate of the country is nearly $1.8 \%$ and if per capita consumption of rice is expected to be $400 \mathrm{gm}$ of rice per day then the demand for rice in 2025 will be $130 \mathrm{~m}$. tones. For obtaining the high yield with seed planting equipment or planter, it is very essential to drop the paddy seeds in rows maintaining accurate seed rate and seed spacing with minimum damage to seeds during metering. This mainly depends on forward speed of the planting equipment, peripheral speed of metering plate and area of cells on the plate. The relationship between these factors and the performance parameters viz. seed rate, seed spacing and percent seed damage can be established using regression analysis. But they may not be very accurate and may pose to difficulty in the determination of inputs for a set of desired outputs (reverse mapping). Hence, an attempt has been made in this paper to develop the feed forward artificial neural network (ANN) models for the prediction of the performance parameters of an inclined plate seed metering device. The data were generated in the laboratory by conducting experiments on a sticky belt test stand provided with a seed metering device and an opto-electronic seed counter. The generated data was used to develop both statistical and neural network models. The performance of the developed models was compared among themselves for 4 randomly generated test cases. The results show that the ANN model predicted the performance parameters of the seed metering device better than the statistical models. In order to determine the optimum forward speed of the planter, peripheral speed of the metering plate and the area of cells on the plate to obtain the recommended seed rate of 104.68 seeds $/ \mathrm{m}^{2}$, seed spacing of 100.04 $\mathrm{mm}$ and percent seed damage of $0.19 \%$ with $100 \%$ fill of the cells, a novel technique of reverse mapping using ANN model was followed. It was observed that the optimum forward speed of the planting equipment and optimum area of cells on the metering plate had good correlation with size of seed. Linear regression equations were developed to predict the optimum forward speed of the planting equipment and optimum area of cells on the metering plate using the size of seeds as independent parameters. The peripheral speed of the metering plate of $0.150 \mathrm{~m} / \mathrm{s}$ was found to be optimum for the size of seeds in the range of 33.67-41.01 $\mathrm{mm}^{2}$. However the results need to be verified by conducting planting operation under actual field conditions. 


\section{Introduction}

Rice is one of the principal commercial crops in India cultivated in about 44 million-hectare area.

Sustainable improvement in the livelihoods of poor farmers in developing countries depends largely on the adoption of improved, resourceconserving cropping systems. These systems will often be based on methods involving direct seeding implements, but adaptation is usually needed to suit local soils, crops and conditions. A major constraint to adoption of improved resource-conserving cropping systems in developing countries is the lack of simple planting equipment.

Farmers in the rural areas use broadcasting or transplanting to sow paddy seeds; often times more than the required numbers of the seed are dropped in a row and covered. Planting seeds through this means is labour- intensive (Bamiro et al, 1986). Timeliness of field operation in seed planting has been identified as a major factor increasing the intensity of cropping (Ojha and Michal, 2012). Hence, there is a necessity to mechanize seeding operation. According to Bamgboye and Mofolasayo (2006), the traditional planting method is tedious, causing fatigue and backache due to the longer hours required for careful hand metering of seeds if crowding or bunching is to be avoided. In rain fed conditions the success of crop production depends on timely seeding. The seed rate for various dry land crops varies from 4 to 140 $\mathrm{kg} / \mathrm{ha}^{-1}$. Availability of a multi crop planter with replaceable metering plate is crucial to meet the seed rate requirements and to reduce the cost involved in machinery management. Though different types of planters having different seed metering mechanisms were evolved, their performance is not up to the mark.
Seed metering device is a heart of seed sowing machine which is evaluated for seed distance, seed size between seed varieties. Seed metering devices meter the seed from the seed box and deposit it into the delivery system that conveys the seed for placement on or in the seedbed. The major functional requirements of seed metering systems are to meter the seed at a predetermined rate/output (e.g. $\mathrm{kg} / \mathrm{ha}^{-1}$ or seeds/meter of row length) meter the seed with the required accuracy (spacing) to meet the planting pattern requirements (i.e. drill seeding, precision drilling, etc); and cause minimal damage to the seed during the metering process. The seed sowing machine is a key component of agriculture field. The performance of seed sowing device has a remarkable influence on the cost and yield of agriculture products.

Under actual field conditio0ns cell may fail to pick up any seed or cell may pick up and drop more than one seed at a point or seed may not emerge from soil due to damage of seed during metering (Kachman and Smith, 1995; Singh et al., 2005) thereby leading to variation in seed spacing, seed rate and plant population (number of plants/unit area).

In order to achieve the uniformity in seed spacing and accuracy in seed rate, it is essential to use the metering plate with size of cells matching to the size of seeds (Jayan and Kumar, 2004; Korayem et al., 1986). Further, size of cell coupled with speed of rotation of the metering plate significantly affects cell fill and seed damage (Singh et al., 2005; Barut and Ozmerzi, 2004; Santos et al., 2003). Hence, it is essential in a planting equipment with inclined plate seed metering device to first select a metering plate of suitable cell size and operate it at the rotary speed that shall result in $100 \%$ cell fill and minimum seed damage, and then adjust the forward speed of the planting equipment to obtain the recommended seed rate and seed spacing. This 
necessitates the development of highly accurate models for the seed rate, seed spacing and percent seed damage based on the independent design and operational parameters like, size of seed, forward speed of planting equipment, rotary speed of the metering plate and size of cell on the plate. Based on the models, the values of design and operational parameters for achieving the $100 \%$ fill of the cells along with desired seed rate and seed spacing can be obtained using suitable optimization techniques.

In the present work, an attempt is made to develop soft computing based models such as feed forward artificial neural network to model the seed rate, seed spacing and percent seed damage by the inclined plate metering device. The statistical regression models might be able to predict the dependent parameters accurately. However, these models are independent in the sense that each response is determined separately as a function of input variables. But, in actual practice, all the responses are measured for a particular set of input parameters. Hence, it is necessary to think for an alternative, which will consider all input parameters and responses as an integral system. Moreover, determination of set of input parameters (forward speed of the planting equipment, rotary speed of the metering plate and area of cell on the plate) for a set of desired outputs (seed rate, seed spacing and percent seed damage at $100 \%$ fill of cells) is an important practical requirement. Reverse mapping (i.e., to predict the inputs for a set of desired outputs) might be difficult to carry out by using response equations obtained through statistical analysis. As the models are developed independently, the interdependency of the output responses might be lost in statistical models. While it presents no problem in the development of a model that maps $n$ sets of possible design and operational parameters into the same response, a reverse mapping can only capture one of these $n$ relations. It is always better to have a number of solutions for achieving the given desired target so that one of which is most appropriate can be chosen for the purpose of a better operation in the field. It is important to mention that reverse mapping can be carried out using the forward mapping models in an optimization framework and it can be solved using an optimizer, say a genetic algorithm (GA). However, it is difficult to obtain the required information related to the set of desired output parameters and constraints quickly, as optimization might be a timeconsuming process. In the present work, an attempt is made to use the forward mapping ANN model of the inclined plate seed metering device in a reverse direction to generate the optimum values of forward speed of the planting equipment, rotary speed of the metering plate and area of cell on the plate for achieving the desired seed rate and seed spacing with minimum seed damage and $100 \%$ cell fill.

Feed forward artificial neural networks (ANNs) are currently being used in a variety of applications with great success. Their first main advantage is that they do not require a user-specified problem solving algorithm (as is the case with classic programming) but instead they "learn" from examples, much like human beings. Their second main advantage is that they possess inherent generalization ability. This means that they can identify and respond to patterns that are similar but not identical to the ones with which they have been trained. Examples of the modeling of the performance parameters of agricultural machinery using artificial neural network are limited. Hall (1992) developed ANN model to predict grain breakage, grain dockage, threshing loss, separator loss and cleaner loss of a combine harvester for harvesting wheat crop. Each performance parameter of the machine was predicted using a neural network of 15-6-4-1 configuration. He reported that the 
ANN model might be adapted to fit local conditions with the addition of relatively few cases of training data and in cases where outliers exist in data, ANN models were less sensitive than conventional regression analysis.

The literatures on the use of various optimization techniques for the determination of design and operational parameters of agricultural machinery are available to a limited extent. In most of the works, power required for farm operations and size of implements has been optimized using optimization techniques like least cost method (Butani and Singh, 1994; Dash and Sirohi, 2008) and genetic algorithms (Parmer et al., 1996). Hansson (1995) optimized the parameters describing the characteristics of a passive non-linear cab suspension of an agricultural tractor using an evolution algorithm. The objective of the optimization was to minimize the total vibration load on the driver. Yazgi and Degirmencioglu (2007) used response surface methodology (RSM) to determine the optimum levels of vacuum pressure, diameter of the seed holes and peripheral speed of the seed plate for the precision planting of cotton seeds. The optimum levels of vacuum pressure and the diameter of holes for precision seeding of cottonseeds were found to be $5.5 \mathrm{kPa}$ and $3 \mathrm{~mm}$, respectively. No optimum value was obtained

Kushwaha and Zhang, 1998 used the radial basis function (RBF) network for predicting draft requirement, energy requirement, final soil condition and tool wear of an agricultural tool operating at high speed. The number of hidden units was determined during the training of network according to the given goal error. They found that the ANN model was able to recognize the output response related to input patterns that are fuzzy and have uncertain properties such as soil and tool types. Al-Janobi et al., (2001) used ANN with 4-24-12-1 configuration to predict the specific draft of agricultural implements using different sites, tillage implements, plowing depths and operating speeds as the input parameters. They reported the correlation coefficient and mean squared error of 0.987 and 0.1445 , respectively between the measured and predicted specific draft. Ma et al., (2006) developed a cutting performance model of a sugarcane harvester using a 3- 3-1 neural network with driving speed of the machine, rotational speed and dip angle of cutting dish as input parameters. The results of the neural network were compared with that of fuzzy comprehensive evaluation method for the new set of input parameters and they reported that the neural network was able to extract the similarities and discrepancy among samples. Here, an attempt is made to explore the ability of the neural network model. The present work consists of the following objectives, which are (i) development of statistical and feed forward artificial neural network models for the prediction of performance parameters of an inclined plate metering device (ii) determination of optimum values of design and operational parameters of the seed metering device for obtaining the desired values of performance parameters by using the developed ANN models in a reverse direction.

\section{Materials and Methods}

\section{Data collection}

Three distinct and most popular varieties of paddy (IR-36, HMT and Javaful) grown in India were selected. Average physical dimensions of the 100 good quality seeds of each variety are presented in Table 1 . For each variety, three metering plates of $120 \mathrm{~mm}$ diameter, $5 \mathrm{~mm}$ thick with 24 equal sized oblong rectangular shaped cells were prepared. Size of cell on each plate was 
decided based on the size of the variety of paddy for which it was prepared (Anantachar et al., 2010). The half distance of the minor axis of the cell of one of the plates was chosen $10 \%$ more than half breadth of the seed. The other 2 plates had the half distance of the minor axis of the cell 1 and $2 \mathrm{~mm}$ more than that of the minor axis of the first plate. The dimensions of the cell of the metering plate selected for each variety are presented in Table 2. A sticky belt test stand along with seed metering device and opto-electronic seed counter was used for the performance evaluation of metering plates. The span and width of the belt was $5 \mathrm{~m}$ and $60 \mathrm{~cm}$, respectively. The selected metering plate was fixed in the seed metering device for its performance evaluation. The drive to the metering plate was given from a transmission wheel through a variable speed set of belt and pulley to vary its speed of rotation. Optoelectronic seed counter was provided in the seed tube through which seeds picked up by the metering plate passes and falls on the sticky belt. Instead of operating the seed metering device using a $5 \mathrm{hp}$ electric motor at the linear speed equal to the forward speed of tractor mounted planting equipment in field. The linear speed of belt was varied by varying the velocity ratio between motor shaft and belt drive shaft.

In India, speed of seed metering by metering plate of the tractor mounted planting equipment varies from 6 to 20 seeds/s and forward speed varies from 2.0 to $5.0 \mathrm{~km} / \mathrm{h}$ under actual field conditions (Chauhan et al., 1999; Sahoo and Srivastava, 2000; Shrivastava et al., 2003; Kamble et al., 2003). Keeping these points in mind, four levels of the peripheral speed of the metering plate viz., $0.05,0.11,0.14$ and $0.17 \mathrm{~m} / \mathrm{s}(9-24 \mathrm{rpm})$ and three levels of linear speed of the sticky belt (forward speed of the planting equipment) viz., $2.0,3.5$ and $5.0 \mathrm{~km} / \mathrm{h}$ were considered for the experiment for each of the three metering plates developed for three varieties of paddy seed. Experiments were conducted by filling the uniform sized and good quality seeds in the hopper such that a constant vertical seed column of $40 \mathrm{~mm}$ is maintained on the seed metering plate. The selected metering plate was operated for 50 rotations at the specified speed. The belt was operated at the selected linear speed to a distance of $4 \mathrm{~m}$ to collect the seed falling from the metering device. The reading shown by the seed counter was noted down at the end of each run considering the appropriate correction factor for the efficiency of seed count by the seed counter. The distance between the seeds collected on the belt was measured using a scale. The actual seed rate and seed damage were determined as follows:

$S R=\frac{S C \times N}{(5.3014 \times V)}$

$S D=\left(\frac{w_{d}}{w_{t}}\right) \times 100$

Where, SR refers to the seed rate in number of seeds $/ \mathrm{m}^{2}$, SC refers to the seed counter reading after appropriate correction factor, $\mathrm{N}$ refers to the rotary speed of the metering plate in $\mathrm{m} / \mathrm{s}, \mathrm{V}$ refers to the linear speed of the sticky belt in $\mathrm{km} / \mathrm{h}$, SD refers to percent seed damage, $W_{d}$ refers to the weight of visible damaged seeds and $W_{t}$ refers to the total weight of seeds metered. The constant value of 3.534 in Eq. (1) was calculated based on row spacing of $20 \mathrm{~cm}$.

The most common row spacing and seed spacing recommended for the paddy varieties is 10 and $10 \mathrm{~cm}$, respectively (Bhowmik et al., 2012). For each combination of independent variables, three observations were made to minimize the error of variation and the average value was considered. Thus, a set of 36 data were collected for each variety of paddy seed and they are presented in Figures 2, 3 and 4. Figure 3 indicates that the seed rate increased with increase in peripheral speed of 
the metering plate and increase in cell area on the plate. The seed spacing decreased with increase in peripheral speed of the metering plate and increase in cell area on the plate. Increase in the forward speed of the planting equipment, decreased the seed rate and increased the seed spacing. The percent seed damage increased with increase in the peripheral speed of the metering plate (Fig. 4). The percent seed damage was higher for the metering plate of larger cell area than that of the metering plate of smaller cell area. Maximum percent seed damage was found to be $0.33 \%$. This is less than the maximum allowable seed damage $(0.5 \%)$ in a seed metering device of the seed drill and planter (RNAM, 1995). These sets of data were used for training the neural network. Again, a set of 8 data were generated for each variety of paddy seed by varying the speed of rotation of metering plate and forward speed. The first and second sets of 4 data were used for the validation and testing of the network, respectively. Table 3 shows response-wise mean and standard deviation (S.D.) values of the training, validation and test cases considered in the present study.

\section{Development of statistical and neural network models for the performance parameters of inclined plate seed metering device}

\section{Development of statistical models}

The purpose of modeling performance parameters of inclined plate seed metering device is to establish its input (forward speed of planting equipment, peripheral speed of metering plate and cell area on the plate) output (seed rate, seed spacing and percent seed damage) relationships.

The statistical models were developed for each performance parameter of the metering device using SPSS 10.0 software for Windows (SPSS South Asia). Linear regression equation was developed for each performance parameter by stepwise regression method. The software developed the following type of equation for the seed rate (number of seeds $/ \mathrm{m}^{2}$ ) and seed spacing $(\mathrm{mm})$ :

$$
Y_{1}=a_{0}+a_{1} V+a_{2} N+a_{3} A
$$

where, $Y_{1}$ is the dependent parameter (seed rate in no. of seeds $/ \mathrm{m}^{2}$ or seed spacing in $\mathrm{mm}$ ). For the percent seed damage, the software developed the following linear model:

$Y_{2}=b_{0}+b_{1} N+b_{2} A$

where, $\mathrm{Y} 2$ is the percent seed damage $(\%)$. V represents forward velocity $(\mathrm{km} / \mathrm{h}) . \mathrm{N}$ represents speed of rotation of the metering plate $(\mathrm{m} / \mathrm{s})$ and A represents cell area $\left(\mathrm{mm}^{2}\right)$. $a_{o}$ and $b_{o}$ are the constants and $a_{1}, a_{2}, a_{3}, b_{1}, b_{2}$ are the regression coefficients.

\section{Development of neural network models}

Feed forward artificial neural network model was developed for each variety of paddy seed for modeling the performance parameters. In the present work, neural network is assumed to be consisting of three or four layers of neurons, i.e., one input layer, one or two hidden layers and one output layer. Many researchers (Hornik, 1993; Bishop, 1995; Ripley, 1996; Benardos and Vosniakos, 2007) have reported that one hidden layer with an arbitrarily large number of neurons is sufficient for the pattern recognition. Maximum two hidden layers are considered in the present study for the better approximation of the output parameters. Three neurons were considered in both input and output layers to represent the three input parameters and responses. The optimal number of hidden layers and neurons in each of them were obtained through genetic algorithm (GA) as single objective constrained optimization problem. A neural network of 3-4-2-3 
configuration was found to be most suitable for variety-1. For the variety-2 and -3 , neural network of 3-3-3 and 3-4-3 configuration, respectively was found to be most optimum. The input data used in the network training, validation and testing processes were normalized between -1 and +1 using the following expression:

$X_{\text {norm }}=\left[\frac{2\left(X-X_{\min }\right)}{X_{\max }-X_{\min }}\right]-1$

Similarly, the output data were normalized between 0 and 1 using the following expression:

$X_{\text {norm }}=\left[\frac{X-X_{\min }}{X_{\max }-X_{\min }}\right]$

where, $X_{\text {norm }}$ is the normalized value of a variable, $X$ indicates the value before normalization, $X_{\min }$ and $X_{\max }$ are the minimum and maximum values of the variable, respectively. Due to the availability of a powerful training algorithm called back propagation, multilayer feed forward neural networks are most popular for modeling applications. A multilayer neural network with four layers (one input layer, two hidden layers, and one output layer) used for modeling purposes is shown in Fig. 1. Referring to the notation in Fig. $1, \mathrm{X}=\left(\mathrm{x}_{1}, \ldots, \mathrm{x}_{\mathrm{i}}, \ldots, \mathrm{x}_{\mathrm{m}}\right)$ is the input vector, $\mathrm{G}=\left(\mathrm{g}_{1}, \ldots, \mathrm{g}_{\mathrm{i}}, \ldots, \mathrm{g}_{\mathrm{n}}\right), \mathrm{H}=$ $\left(\mathrm{h}_{1}, \ldots, \mathrm{h}_{\mathrm{k}}, \ldots, \mathrm{h}_{\mathrm{p}}\right)$, and $\mathrm{Y}=\left(\mathrm{y}_{1}, \ldots, \mathrm{y}_{1}, \ldots\right.$, $\mathrm{y}_{\mathrm{q}}$ ) are the outputs of the first hidden layer, second hidden layer, and output layer, respectively, $\mathrm{u}_{\mathrm{ij}}$ is the weight of the synaptic joint between the ith input and the jth neuron in the first hidden layer, $v_{\mathrm{jk}}$ is the weight of the synaptic joint between the jth neuron in the first hidden layer and the kth neuron in the second hidden layer, and $\mathrm{w}_{\mathrm{kl}}$ is the weight of the synaptic joint between the kth neuron in the second hidden layer and the lth neuron in the output layer. The bias value of the neurons in the first hidden layer, second hidden layer and output layer is given by $\left[\mathrm{B}_{11}, \ldots, \mathrm{B}_{1 \mathrm{j}}, \ldots\right.$,
$\left.\mathrm{B}_{1 \mathrm{n}}\right],\left[\mathrm{B}_{21}, \ldots, \mathrm{B}_{2 \mathrm{k}}, \ldots, \mathrm{B}_{2 \mathrm{p}}\right],\left[\mathrm{B}_{\mathrm{ol}}, \ldots, \mathrm{B}_{\mathrm{ol}}, \ldots\right.$ ., $\left.\mathrm{B}_{\mathrm{oq}}\right]$, respectively. The output of the neural network can be computed as

$y_{1}=\frac{1}{1+e^{-\gamma_{1}}}$

where, $\gamma_{1}$ is the weighted total input to the output neuron 1 , which is defined as

$\gamma_{1}=\sum_{k=1}^{p} h_{k} w_{k l}+B_{o l}$

and $\mathrm{p}$ is the number of neurons in the second hidden layer. Similarly, the output of the second hidden layer $\mathrm{H}$ can be expressed as a function of the output of the first hidden layer $\mathrm{G}$, which can, in turn, be expressed as a function of the input vector $X$. The back propagation training algorithm aims to adjust the weights and bias values of a feed forward neural network in order to minimize the sumsquared error of the network, which is defined as

$E=\sum_{m=1}^{s}\left[\frac{1}{2} \sum_{l=1}^{q}\left(d_{m l}-y_{m l}\right)^{2}\right]$

where $S$ is the number of training data points, $\mathrm{q}$ is then number of output variables, and $\mathrm{d}_{\mathrm{m}}=$ $\left[\mathrm{d}_{\mathrm{m} 1} \mathrm{~d}_{\mathrm{m} 2} \ldots \mathrm{d}_{\mathrm{mq}}\right]$ and $\mathrm{y}_{\mathrm{m}}=\left[\begin{array}{lll}\mathrm{y}_{\mathrm{m} 1} & \mathrm{y}_{\mathrm{m} 2} \ldots \mathrm{y}_{\mathrm{mq}}\end{array}\right]$ are the $m$ th desired and calculated output vectors, respectively. This is typically done by continually changing the values of the weights in the direction of steepest descent with respect to the error function $\mathrm{E}$ as given below:

$$
\begin{aligned}
& \left(\Delta w_{k l}\right)_{t}=-L\left(\frac{\partial E}{\partial w_{k l}}\right)_{t} \\
& \left(\Delta B_{o}\right)_{t}=-L\left(\frac{\partial E}{\partial \gamma_{l}}\right)_{t}
\end{aligned}
$$

Where ${ }^{\Delta}$ indicates the change in values, $\mathrm{L}$ 
indicates the learning rate and $\mathrm{t}$ indicates the iteration number. $\partial E / \partial w_{k l}$ and $\partial E / \partial_{y l}$ can be determined using the chain rule of differentiation as given below:

$\frac{\partial e}{\partial w_{k l}}=\sum_{l=1}^{q} \frac{\partial E}{\partial y_{l}} \cdot \frac{\partial y_{l}}{\partial y_{l}} \cdot \frac{\partial y_{l}}{\partial w_{k l}}=\sum_{l=1}^{q}\left(d_{1}-y_{1}\right) \cdot y_{1} *\left(1-y_{l}\right) y_{k}$

$\frac{\partial E}{\partial y_{l}}=\sum_{l=1}^{q} \frac{\partial E}{\partial y_{l}} \cdot \frac{\partial y_{l}}{\partial y_{l}}=\sum_{l=1}^{q}\left(d_{1}-y_{1}\right) \cdot y_{1} \cdot\left(1-y_{1}\right)$

where, yl and _l represent the output and input, respectively of the lth neuron lying on the output layer (Jang et al., 2005). This process is called the training of the network. At the end of every training iteration (epoch), overall training error (absolute relative percent error) was calculated as given below:

$E_{\text {training }}=\sum_{m=1}^{8}\left[\sum_{l=1}^{q} \frac{d_{m l}-y_{m l}}{d_{m l}}\right]$

network and the responses were predicted. The generalization error was computed in the similar way as that of the training error. The above process was repeated several times (epochs or iterations) till the computed generalization error remains constant for a predefined number of epochs or starts to increase rapidly (Doan and Liong, 2004). This is called early stopping technique. The final weights of the synaptic joints and bias values were stored for further analysis.

Determination of optimum values of design and operational parameters of the inclined plate seed metering device

\section{Reverse mapping}

The function of a neural network model of the inclined plate seed metering device is to predict the performance parameters of the metering device corresponding to given design and operational parameters. Since the objective is to determine the optimum values of design and operational parameters of the metering device that produce the desired levels of performance parameters, it would be ideal if the developed model can be used in a reverse direction to generate deign and operational parameters that will produce the desired levels of performance parameters. A neural network system cannot be developed for the direct mapping from the outputs to the inputs (Wu and Vai, 1997). Due to this limitation, a conventional optimization process (like GA) using a neural network involves two iterative steps: (1) Use a searching method independent of the neural network itself to identify a set of input parameters; and (2) Feed the input parameters to the neural network to obtain a set of corresponding output parameters. These two steps are repeated until the outputs determined in step 2 are substantially close to the predetermined desired outputs. Instead of pursuing an explicit optimization technique using the developed models, a novel approach (Wu and Vai, 1997; Vai et al., 1998) in which the searching of a solution is performed with amodified neural network learning process, is developed. This approach begins by training a neural network to model the performance parameters of the metering device. As described in Section 3.2, the weights of the neural network are adjusted at this stage to minimize its error function given by (11). The solution searching is then performed by applying a modified back propagation learning rule to the trained network. An initial solution of design and operational parameters of the metering device (input variables) is taken and the trained neural network model is used to predict the outcome of this solution. The difference between the desired outcome (seed rate, seed spacing and percent seed damage) and the one corresponding to the current solution is calculated and back propagated 
through the layers in the neural network. Instead of adjusting the neural network weights, as originally done in the training of the neural network, the input variables are modified to minimize the error function defined in (11), while the weights and bias values are kept unchanged. This is a very simple modification of the learning process because we can simply exchange the roles of weights and inputs in the back propagation learning rule. This modified learning rule can be described as,

$$
\left(\Delta x_{i}\right)_{t}=-L\left(\frac{\partial E}{\partial x_{i}}\right)_{t}
$$

and

$$
\begin{aligned}
\frac{\partial E}{\partial x_{i}}=\sum_{k=1}^{q} \sum_{k=1}^{n} \sum_{j=1}^{n} \frac{\partial E}{\partial y_{1}} \cdot \frac{\partial y_{1}}{\partial y_{l}} \frac{\partial y_{l}}{\partial h_{k}} \cdot \frac{\partial h_{k}}{\partial y_{k}} \cdot \frac{\partial y_{k}}{\partial g_{k}} \cdot \frac{\partial g_{j}}{\partial y_{j}} \cdot \frac{\partial y_{j}}{\partial x_{i}} \\
=\sum_{k=1}^{q} \sum_{k=1}^{n} \sum_{j=1}^{n}\left(d_{l}-y_{1}\right) \cdot y_{l} \cdot\left(1-y_{1}\right) \cdot w_{k l} \cdot h_{k} \cdot\left(1-h_{k}\right) \cdot v_{j k}{ }^{\prime} g_{j} \cdot u_{i j}
\end{aligned}
$$

All the variables are as defined in Section 3.2. It is evident that the operations described in (16) can be carried out in a distributed fashion. Each neuron can utilize values propagated back from the next layer to calculate its associated terms and, in turn, send the results to the previous layer. The above process is repeated several times for each data of the training dataset till either the computed error function defined in (11) becomes a very small value or maximum of 10,000 iterations are reached. The final solutions which results in the desired outcome are stored.

The reverse mapping steps proposed above, allows the solution searching routine to be implemented along with the training and modeling operations. There is no need of an external optimization routine for the solution searching. Since the forward mapping model is used, all the relations between input parameters and outcomes are retained. Another significant property of this design approach is that multiple solutions, if they exist in the modeled system, can be found typically with different initial solutions. This allows the selection of the best solution from among the multiple solutions from the point of view of applications in actual field conditions.

Desired performance parameters of the metering device and selection of the best solution

As the recommended row spacing and seed spacing for paddy is 10 and $10 \mathrm{~cm}$, respectively, seed metering device should be set to give the seed rate $104.68 \mathrm{seeds} / \mathrm{m}^{2}$. The percent seed damage during metering was well within $0.5 \%$, which is the maximum allowable seed damage in planting equipment. Considering these facts, the desired outcome (performance parameters) of the seed metering device was set as, 104.68 seeds $/ \mathrm{m}^{2}$ seed rate, $100 \mathrm{~mm}$ seed spacing and $0.19 \%$ seed damage. This generated a number of combinations of design and operational parameters of the metering device that shall satisfy the desired outcome. In order to select the best solution from among the multiple solutions, percent cell fill close to 100 was used as a criterion. It is essential that the combination of design and operational parameters should ensure that there is $100 \%$ fill of the cells during metering. Percent cell fill was computed as the ratio of actual seed rate obtained using the combination of design and operational parameters and the theoretical seed rate determined.

\section{Results and Discussion}

The performance parameters of the inclined plate seed metering device developed through statistical modeling and back propagation neural network are presented below. 


\section{Results of statistical modeling}

Table 4 presents the statistical models developed for various performance parameters of the seed metering device. The minimum value of correlation coefficient was 0.867 and this indicates that the developed models are able to represent minimum $86.7 \%$ of the input-output relationship. The performance of the statistical models was tested on the 4 randomly generated data for the testing purpose and the mean absolute generalization error was found to be in the range of 4.83$32.64 \%$. Percent seed damage was independent of the forward velocity. Apart from the obvious variation in seed spacing and seed rate with variation in the forward speed of planting equipment and rotary speed of the metering plate as described in Eqs. (1) and (2), it was observed that the regression coefficients associated with peripheral speed of the metering plate is positive for percent seed damage. This indicates that with increase in peripheral speed of the metering plate, percent seed damage increased. Increase in cell area on the plate, increased the seed rate and percent seed damage, and decreased the seed spacing.

The absolute values of the coefficients associated with peripheral speed of the metering plate are higher than the rest in each model, indicating that the peripheral speed of the metering plate has the highest influence on the performance parameters of the metering device than that of other independent parameters.

\section{Results of neural network modeling}

Neural networks of 3-4-2-3 configuration, 3-33 configuration and 3-4-3 configuration were developed for modeling the performance parameters of the inclined plate seed metering device using variety-1, -2 and -3 , respectively. The values of the constants (weight of the synaptic joints and biases) of the ANN models are presented in Table 5. The mean absolute generalization error for the prediction of individual performance parameter by the ANN model for each variety is given in Table 6. It was found to be varying from 1.38 to $3.29 \%$.

The statistical and ANN models were compared in terms of percent deviation in the prediction of performance parameters of inclined plate seed metering device for the 4 test cases (Fig. 5). The values of percent deviation in prediction of seed rate, seed spacing and percent seed damage by statistical models were found to lie in the ranges of $-54.15-53,4-71$ and $-11-8$, respectively for variety-1, -29-42, 6-63, and $-18-12$, respectively for variety-2, and $-38-42,1-63$ and $-14-1$, respectively for variety-3. As compared to statistical models, the percent deviation in prediction by ANN model was much lower except for 2 data points (cases 1 and 3 of percent seed damage) of each variety. The prediction of performance parameters by ANN models was consistent with maximum percent deviation of $4.35 \%$ for the test cases. The prediction by ANN was better than that of statistical model mainly because of its ability to fully capture the input-output relationship during training of the network and its better generalization ability. This was also proved by the sensitivity analysis of the ANN model. The sensitivity analysis was conducted to determine the relative importance of each input parameter for the prediction of each output parameter. Each input parameter was varied between its mean \pm standard deviations while all other inputs were fixed at their respective means. The change in output caused by the change in input was calculated. The result of the sensitivity analysis when used with variety-1 is presented in Fig. 6 and the similar trend was observed when used with other varieties. Fig. 6 indicates that the forward speed of the planting equipment had the highest influence on seed rate followed by 
peripheral speed of the metering plate. The seed rate was negatively correlated with the metering plate. The seed spacing was highly influenced by peripheral speed of the metering plate followed by forward speed of the planting equipment. The seed spacing was positively correlated with forward speed and negatively correlated with peripheral speed of the metering plate. The percent seed damage was greatly affected by the variation in the peripheral speed of the metering plate. The cell area on the plate and forward velocity had very little influence on the seed damage. The percent seed damage was positively correlated with peripheral speed of the plate. Thus, the trend of variation in the output parameters for the variation in the input parameters matched very closely to the observed variations shown in Fig. 2 and 3. This indicates that the developed ANN model respects the intuitive correlations between the input and output parameters and incorporates this existing domain knowledge in the model.

\section{Results of the reverse mapping of the ANN model}

The developed ANN model for the performance parameters of the inclined plate seed metering device using 3 varieties of paddy were used in reverse direction to determine the various combination of design and operational parameters that result in the desired seed rate of 104.68 seeds $/ \mathrm{m}^{2}$, seed spacing of $100 \mathrm{~mm}$ and percent seed damage of $0.2 \%$. The entire training dataset was passed through the ANN model in reverse direction with learning rate of 0.3. The combinations of forward speed of the planting equipment, peripheral speed of the metering plate and cell area on the plate that resulted in the desired seed rate, seed spacing and percent seed damage were stored. Instead of presenting all the multiple combinations of design and operational parameters to obtain the desired performance parameters, only those with percent cell fill between 99 and $105 \%$ are presented in Table 7. For each variety, any one of the combinations of design and operational parameters listed in Table 7 may be selected. Considering nearly $100 \%$ fill of cells, the combination of design and operational parameters given in italics in Table 7 were selected for each varieties of paddy. This indicated the optimum peripheral speed of the metering plate to be $0.157 \mathrm{~m} / \mathrm{s}$ for variety- 1 and -2 and $0.138 \mathrm{~m} / \mathrm{s}$ for variety- 3 . The variation in the optimum forward speed of the planting equipment and optimum area of cells on the metering plate with size of seeds is shown in Fig. 6. Correlating optimum forward speed of the planting equipment (Vo, $\mathrm{km} / \mathrm{h})$ and optimum area of cells on the metering plate $\left(\mathrm{A}_{\mathrm{o}}, \mathrm{mm}^{2}\right)$ with size of seeds $\left(\mathrm{A}_{\mathrm{s}}, \mathrm{mm}^{2}\right)$, the following relations were developed:

$V_{0}=3.422+0.00536 \mathrm{~A}_{s}$

$A_{0}=47,323+1.213 A_{s}$

The $\mathrm{R}^{2}$ value of 0.883 and 0.992 for the Eqs. (17) and (18), respectively indicates good fit of the relationship. If the size of seeds to be planted is known, the optimum forward speed and size of cells on the metering plate can be selected using the above relations for the seeds in the range of $83.12-123.01 \mathrm{~mm}^{2}$. The peripheral speed of the metering plate of 0.150 $\mathrm{m} / \mathrm{s}$ can be selected for the size of seeds in the range of $29.46-32.74 \mathrm{~mm}^{2}$.

However, the results presented above will only serve the purpose of initial approximation in the selection of design and operational parameters of the inclined plate seed metering device. But it needs to be verified under actual field conditions. It is worth mentioning, that the reverse mapping process using the ANN models is very fast since the number of adjustable variables is significantly reduced from that of forward training. It takes several hours to complete the training of neural network models on a typical work station, but the optimum solution can be found within 10 seconds. 
Table.1 Physical dimensions of the selected varieties of paddy

\begin{tabular}{|lllllll|}
\hline Parameters & $\begin{array}{l}\text { Variety-1 } \\
\text { Mean }\end{array}$ & $\begin{array}{l}\text { Std. error } \\
\text { of mean }\end{array}$ & $\begin{array}{l}\text { Variety-2 } \\
\text { Mean }\end{array}$ & $\begin{array}{l}\text { Std. error } \\
\text { of mean }\end{array}$ & $\begin{array}{l}\text { Variety-3 } \\
\text { Mean }\end{array}$ & $\begin{array}{l}\text { Std. error } \\
\text { of mean }\end{array}$ \\
\hline Length, $\mathrm{mm}$ & 9.28 & 0.03 & 8.25 & 0.02 & 6.02 & 0.03 \\
$\begin{array}{l}\text { Breadth, mm } \\
\text { Area, mm }\end{array}$ & 2.54 & 0.04 & 2.43 & 0.03 & 2.26 & 0.02 \\
$\begin{array}{l}\text { Half distance of the } \\
\text { minor axis, mm }\end{array}$ & 1.39 & 0.04 & 33.67 & 0.05 & 21.08 & 0.05 \\
& & & 1.33 & 0.02 & 1.24 & 0.04 \\
\hline
\end{tabular}

Table.2 Dimensions of the cell of the metering plates

\begin{tabular}{|c|c|c|c|c|c|c|}
\hline \multirow{2}{*}{$\begin{array}{l}\text { Metering } \\
\text { plates }\end{array}$} & \multicolumn{2}{|l|}{ Variety-1 } & \multicolumn{2}{|l|}{ Variety-2 } & \multicolumn{2}{|l|}{ Variety-3 } \\
\hline & $\begin{array}{l}\text { Half } \\
\text { distance of } \\
\text { minor axis } \\
\text { of the cell, } \\
\mathrm{mm}\end{array}$ & $\begin{array}{l}\text { Area of the } \\
\text { single cell, } \\
\mathrm{mm}^{2}\end{array}$ & $\begin{array}{l}\text { Half } \\
\text { distance of } \\
\text { minor axis } \\
\text { of the cell, } \\
\mathrm{mm}\end{array}$ & $\begin{array}{l}\text { Area of the } \\
\text { single cell, } \\
\mathrm{mm}^{2}\end{array}$ & $\begin{array}{l}\text { Half } \\
\text { distance of } \\
\text { minor axis } \\
\text { of the cell, } \\
\mathrm{mm}\end{array}$ & $\begin{array}{l}\text { Area of the } \\
\text { single cell, } \\
\mathrm{mm}^{2}\end{array}$ \\
\hline 1 & 2.39 & 77.18 & 2.33 & 64.58 & 2.24 & 41.80 \\
\hline 2 & 1.89 & 61.03 & 1.83 & 50.72 & 1.74 & 32.47 \\
\hline 3 & 1.39 & 41.01 & 1.33 & 33.67 & 1.24 & 21.08 \\
\hline
\end{tabular}

Table.3 Response-wise mean and standard deviation of the training validation and test cases

\begin{tabular}{|lllllll|}
\hline Response & \multicolumn{2}{l}{ Training data } & \multicolumn{2}{l}{ Validation data } & \multicolumn{2}{l|}{ Test data } \\
\cline { 2 - 7 } & Mean & S.D. & Mean & S.D. & Mean & S.D. \\
\hline Variety-1 & 56.09 & 26.4800 & 55.16 & 25.8523 & 62.42 & 39.8248 \\
Seed rate & 200.81 & 59.5983 & 198.16 & 76.8759 & 202.29 & 74.7256 \\
$\begin{array}{l}\text { Seed spacing } \\
\text { Percent seed damage }\end{array}$ & 0.24 & 0.07561 & 0.24 & 0.0887 & 0.26 & 0.0975 \\
Variety-2 & & & & & & \\
Seed rate & 55.78 & 24.8012 & 54.54 & 26.9860 & 60.24 & 34.1599 \\
Seed spacing & 196.46 & 49.8444 & 201.7026 & 64.2456 & 199.19 & 66.3677 \\
Percent seed damage & 0.24 & 0.07640 & 0.24725 & 0.0886 & 0.26 & 0.1005 \\
Variety-3 & & & & & & \\
Seed rate & 56.27 & 25.1502 & 54.88 & 27.6175 & 59.6 & 32.5775 \\
Seed spacing & 193.21 & 51.0122 & 202.17 & 78.8019 & 196.20 & 64.3433 \\
Percent seed damage & 0.25 & 0.0758 & 0.26 & 0.0822 & 0.27 & 0.1034 \\
& & & & & & \\
\hline
\end{tabular}


Table.4 Statistical models for the performance prediction of inclined plate seed metering device

\begin{tabular}{|c|c|c|c|c|}
\hline $\begin{array}{l}\text { Performance } \\
\text { parameter }\end{array}$ & Statistical model & $\begin{array}{l}\text { Correlation } \\
\text { coefficient, } \\
\mathbf{R}^{2}\end{array}$ & $\begin{array}{l}\text { Mean } \\
\text { absolute } \\
\text { generalization } \\
\text { error }\end{array}$ & $\begin{array}{l}\text { Overall } \\
\text { absolute } \\
\text { generalization } \\
\text { error }\end{array}$ \\
\hline \multicolumn{5}{|l|}{ Variety-1 } \\
\hline Seed rate & $\begin{array}{l}\mathrm{SR}=27.352- \\
15.637 \mathrm{~V}+185.861 \mathrm{~N}+0.171 \mathrm{~A}\end{array}$ & 0.887 & 32.6432 & 23.8845 \\
\hline Seed spacing & $\begin{array}{l}\mathrm{SS}=186.763+30.485- \\
458.155 \mathrm{~N}-0.455 \mathrm{~A}\end{array}$ & 0.867 & 31.5356 & \\
\hline $\begin{array}{ll}\text { Percent } & \text { seed } \\
\text { damage } & \\
\text { Variety-2 } & \end{array}$ & $\begin{array}{l}\mathrm{SD}=- \\
0.0307+0.928 \mathrm{~N}+0.0001544 \mathrm{~A}\end{array}$ & 0.945 & 7.1518 & \\
\hline Seed rate & $\begin{array}{l}\mathrm{SR}=37.250- \\
15.548 \mathrm{~V}+161.541 \mathrm{~N} 0.173 \mathrm{~A}\end{array}$ & 0.906 & 24.1690 & 17.8633 \\
\hline Seed spacing & $\begin{array}{l}\mathrm{SS}=126.554+31.178 \mathrm{~V}- \\
311.727 \mathrm{~N}-0.365 \mathrm{~A}\end{array}$ & 0.921 & 21.2644 & \\
\hline $\begin{array}{ll}\text { Percent } & \text { seed } \\
\text { damage } & \\
\text { Variety-3 } & \end{array}$ & $\begin{array}{l}\mathrm{SD}=- \\
0.0201+0.938 \mathrm{~N}+0.0001804 \mathrm{~A}\end{array}$ & 0.944 & 7.6504 & \\
\hline Seed rate & $\begin{array}{l}\mathrm{SR}=39.291- \\
15.890 \mathrm{~V}+162.127 \mathrm{~N}+0.189 \mathrm{~A}\end{array}$ & 0.912 & 24.3795 & 18.2282 \\
\hline Seed spacing & $\begin{array}{l}\mathrm{SS}=132.291+29.380 \mathrm{~V}- \\
347.129 \mathrm{~N}-0.455 \mathrm{~A}\end{array}$ & 0.880 & 25.1631 & \\
\hline $\begin{array}{l}\text { Percent seed } \\
\text { damage }\end{array}$ & $\begin{array}{l}S D=- \\
0.0311+0.936 \mathrm{~N}+0.0003821 \mathrm{~A}\end{array}$ & 0.965 & 4.8335 & \\
\hline
\end{tabular}

Table.6 Mean absolute generalization error of the ANN models for the prediction of performance parameters

\begin{tabular}{|llllll|}
\hline Variety & ANN & \multicolumn{4}{l|}{ Mean absolute generalization error, percent } \\
& architecture & Seed rate & Seed spacing & Seed damage & Overall \\
& & & & & \\
\hline 1. & $3-4-2-3$ & 2.9796 & 3.8551 & 2.9356 & 2.4551 \\
2. & $3-3-3$ & 1.4179 & 2.7167 & 2.6991 & 2.4310 \\
3. & $3-4-3$ & 1.9533 & 1.7212 & 19536 & 1.7205 \\
\hline
\end{tabular}


Int.J.Curr.Microbiol.App.Sci (2018) 7(10): 3494-3515

Table.5 Constants of the ANN models developed for the 3 varieties of paddy

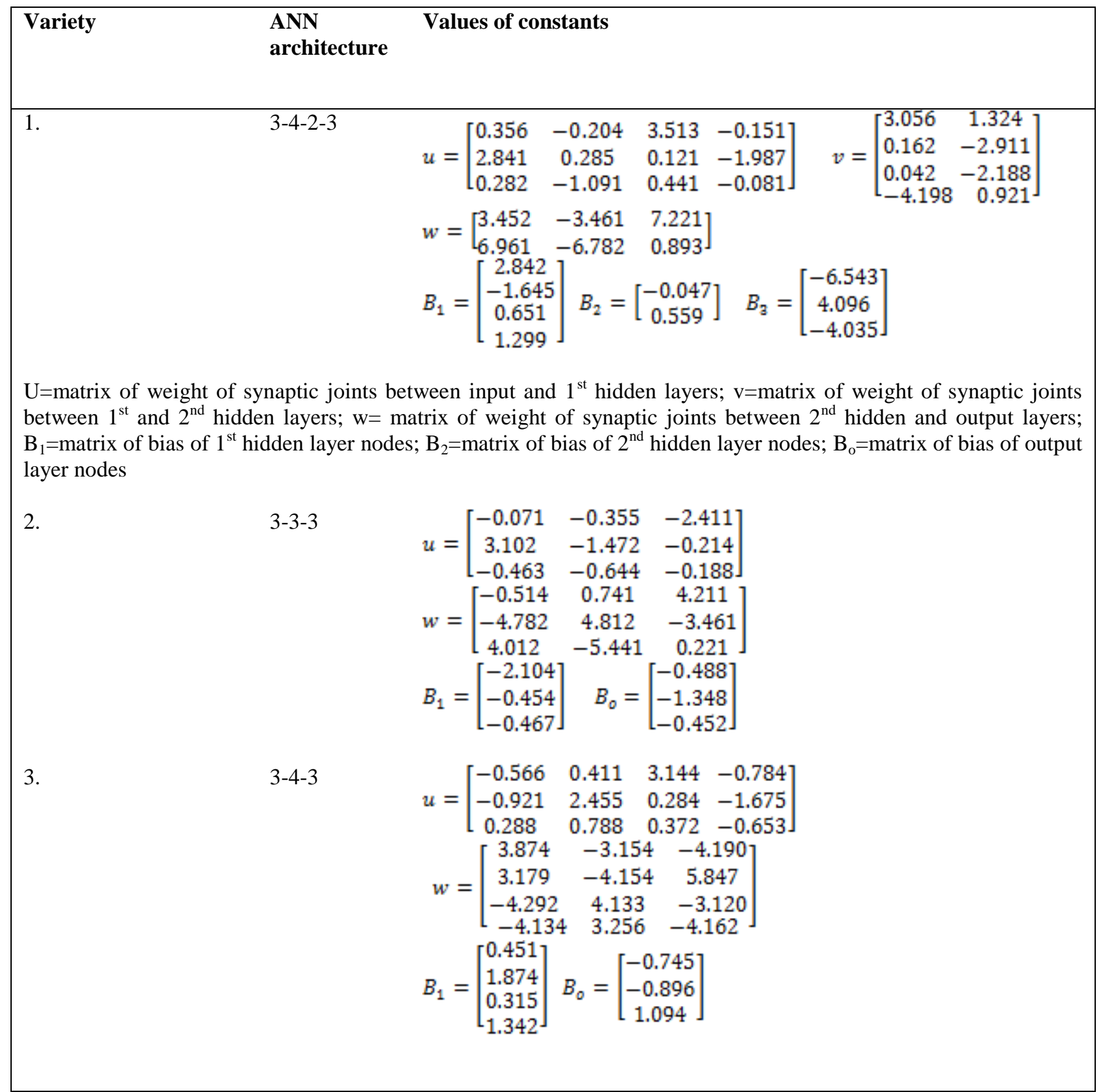

$\mathrm{u}=$ matrix of weight of synaptic joints between input and hidden layers; $\mathrm{w}=$ matrix of weight of synaptic joints between hidden and output layers; $\mathrm{B}_{1}=$ matrix of bias of hidden layer nodes; $\mathrm{B}_{0}=$ matrix of bias of output layer nodes 
Table.7 The multiple combinations of design and operational parameters of the inclined plate seed metering device that resulted in seed rate of 104.68 seeds $/ \mathrm{m}^{2}$, seed spacing $100 \mathrm{~mm}$ and percent seed damage of $0.2 \%$ with percent cell fill of $99-105 \%$

\begin{tabular}{|c|c|c|c|c|c|c|}
\hline \multicolumn{3}{|c|}{ Design and operational parameters } & \multicolumn{4}{|c|}{ Resulting performance parameter } \\
\hline $\begin{array}{l}\text { Forward } \\
\text { speed of } \\
\text { planting } \\
\text { equipment, } \\
\text { km/h }\end{array}$ & $\begin{array}{l}\text { Peripheral } \\
\text { speed of } \\
\text { metering } \\
\text { plate, } \mathrm{m} / \mathrm{s}\end{array}$ & $\begin{array}{lr}\text { Cell area } \\
\text { on } \\
\text { plate, } \mathrm{mm}^{2}\end{array}$ & $\begin{array}{l}\text { Seed rate, } \\
\text { no. of } \\
\text { seeds } / \mathrm{m}^{2}\end{array}$ & $\begin{array}{l}\text { Seed } \\
\text { spacing, } \\
\text { mm }\end{array}$ & $\begin{array}{l}\text { Percent } \\
\text { seed } \\
\text { damage, } \\
\%\end{array}$ & $\begin{array}{l}\text { Percent } \\
\text { cell fill, \% }\end{array}$ \\
\hline \multicolumn{7}{|l|}{ Variety-1 } \\
\hline 3.887 & 0.158 & 45.421 & 106.221 & 99.518 & 0.198 & 102.603 \\
\hline 4.087 & 0.158 & 41.282 & 100.104 & 99.542 & 0.198 & 103.376 \\
\hline 4.142 & 0.157 & 47.399 & 104.842 & 103.078 & 0.200 & 98.857 \\
\hline 4.042 & 0.158 & 44.472 & 105.145 & 102.445 & 0.200 & 102.154 \\
\hline \multicolumn{7}{|l|}{ Variety-2 } \\
\hline 3.918 & 0.157 & 40.487 & 106.332 & 100.089 & 0.198 & 101.299 \\
\hline 3.896 & 0.158 & 36.545 & 106.324 & 100.140 & 0.198 & 102.660 \\
\hline 4.102 & 0.156 & 52.676 & 105.658 & 102.151 & 0.200 & 98.953 \\
\hline 4.187 & 0.157 & 50.576 & 105.671 & 102.125 & 0.200 & 98.977 \\
\hline \multicolumn{7}{|l|}{ Variety-3 } \\
\hline 3.939 & 0.137 & 38.890 & 104.016 & 97.840 & 0.199 & 99.933 \\
\hline 3.945 & 0.137 & 39.294 & 104.102 & 97.878 & 0.199 & 99.805 \\
\hline 3.926 & 0.138 & 35.978 & 103.984 & 97.848 & 0.199 & 100.451 \\
\hline 3.865 & 0.141 & 25.943 & 103.837 & 97.857 & 0.199 & 103.349 \\
\hline
\end{tabular}

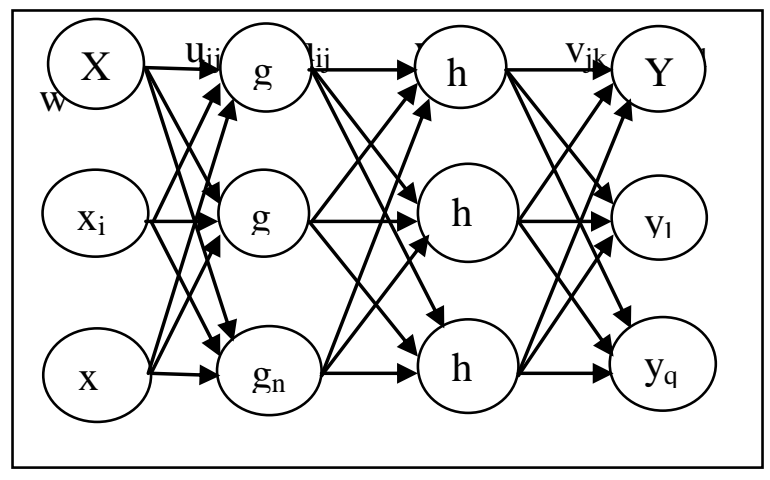

Fig.1 A feed forward neural network with two hidden layers 

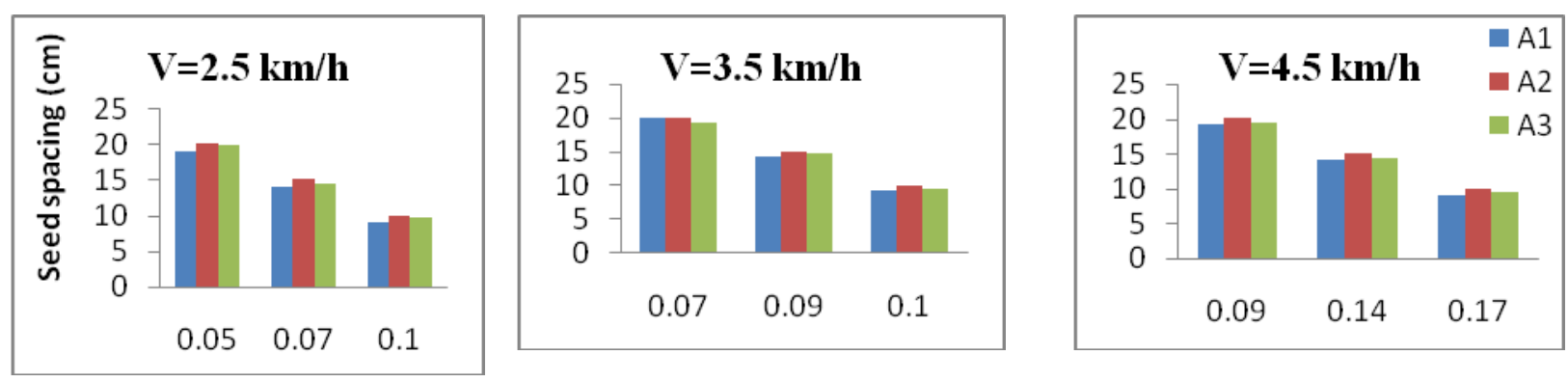

Peripheral speed of metering plate, $\mathrm{m} / \mathrm{s}$ $\mathrm{A} 1=41.01 \mathrm{~mm}^{2}, \mathrm{~A} 2=61.03 \mathrm{~mm}^{2}, \mathrm{~A} 3=77.18 \mathrm{~mm}^{2}$. Variety-1
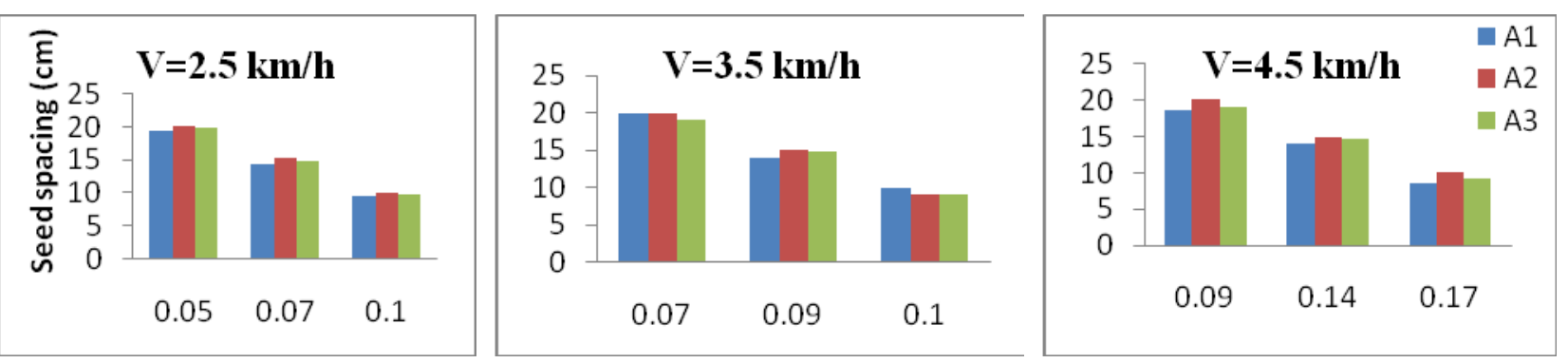

Peripheral speed of metering plate, $\mathrm{m} / \mathrm{s}$ $\mathrm{A} 1=33.67 \mathrm{~mm}^{2}, \mathrm{~A} 2=50.72 \mathrm{~mm}^{2}, \mathrm{~A} 3=64.58 \mathrm{~mm}^{2}$.

Variety-2
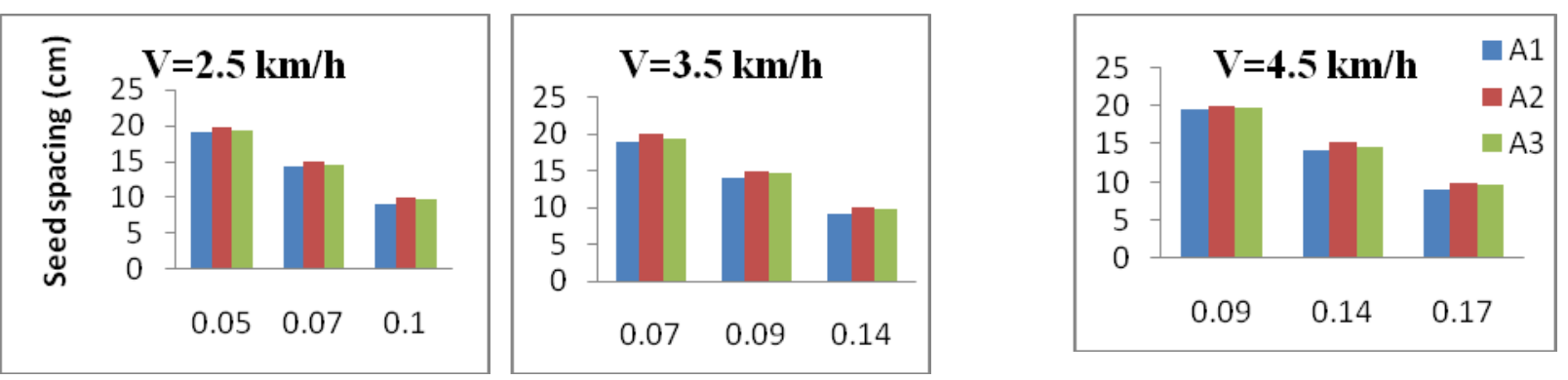

Peripheral speed of metering plate, $\mathrm{m} / \mathrm{s}$ $\mathrm{A} 1=21.08 \mathrm{~mm}^{2}, \mathrm{~A} 2=32.47 \mathrm{~mm}^{2}, \mathrm{~A} 3=41.80 \mathrm{~mm}^{2}$ Variety-3

Fig.2 Variation in seed spacing with peripheral speed of the metering plate at various forward speed of the planting equipment for the 3 varieties. 

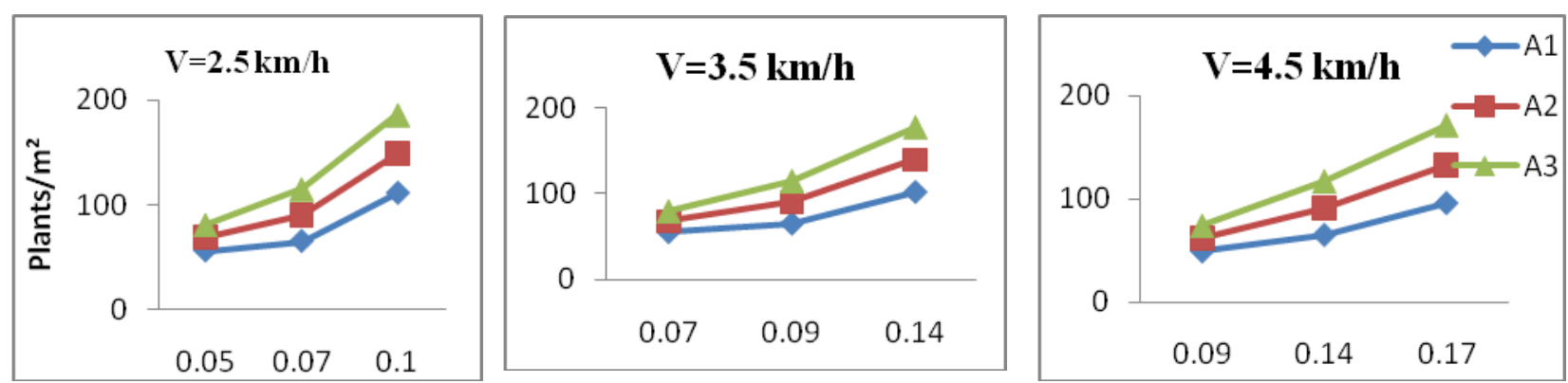

Peripheral speed of metering plate, $\mathrm{m} / \mathrm{s}$ $\mathrm{A} 1=41.01 \mathrm{~mm}^{2}, \mathrm{~A} 2=61.03 \mathrm{~mm}^{2}, \mathrm{~A} 3=77.18 \mathrm{~mm}^{2}$.

Variety-1
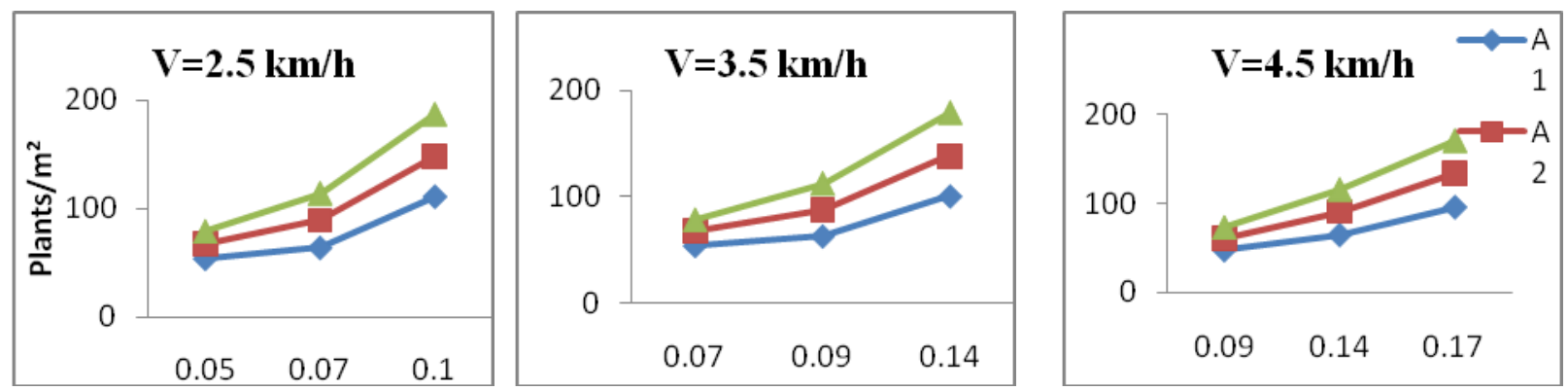

Peripheral speed of metering plate, $\mathrm{m} / \mathrm{s}$ $\mathrm{A} 1=33.67 \mathrm{~mm}^{2}, \mathrm{~A} 2=50.72 \mathrm{~mm}^{2}, \mathrm{~A} 3=64.58 \mathrm{~mm}^{2}$.

Variety-2
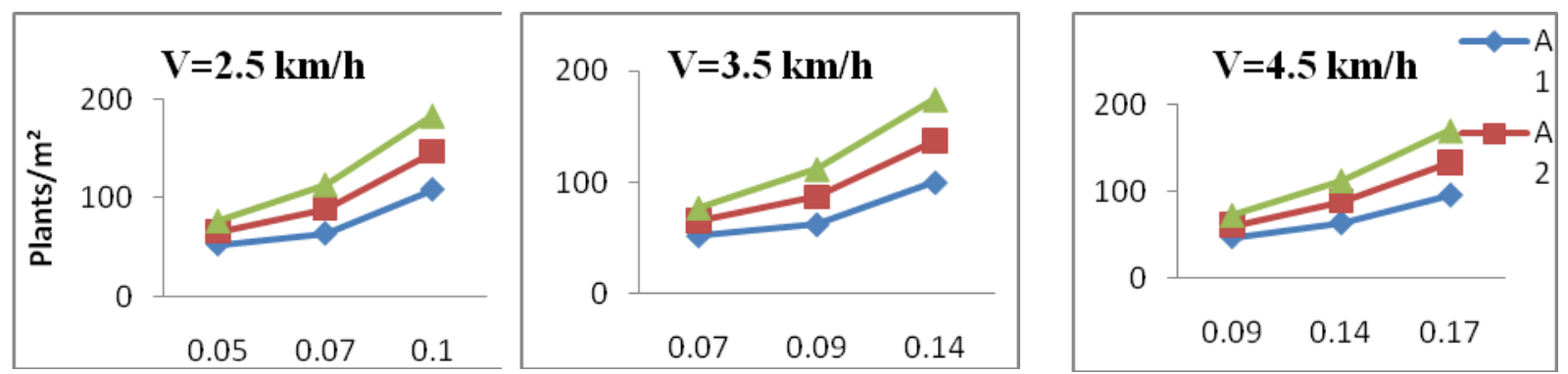

Peripheral speed of metering plate, $\mathrm{m} / \mathrm{s}$

$\mathrm{A} 1=21.08 \mathrm{~mm}^{2}, \mathrm{~A} 2=32.47 \mathrm{~mm}^{2}, \mathrm{~A} 3=41.80 \mathrm{~mm}^{2}$

Variety-3

Fig.3 Variation in seed rate with peripheral speed of the metering plate at various forward speed of the planting equipment for the 3 varieties. 

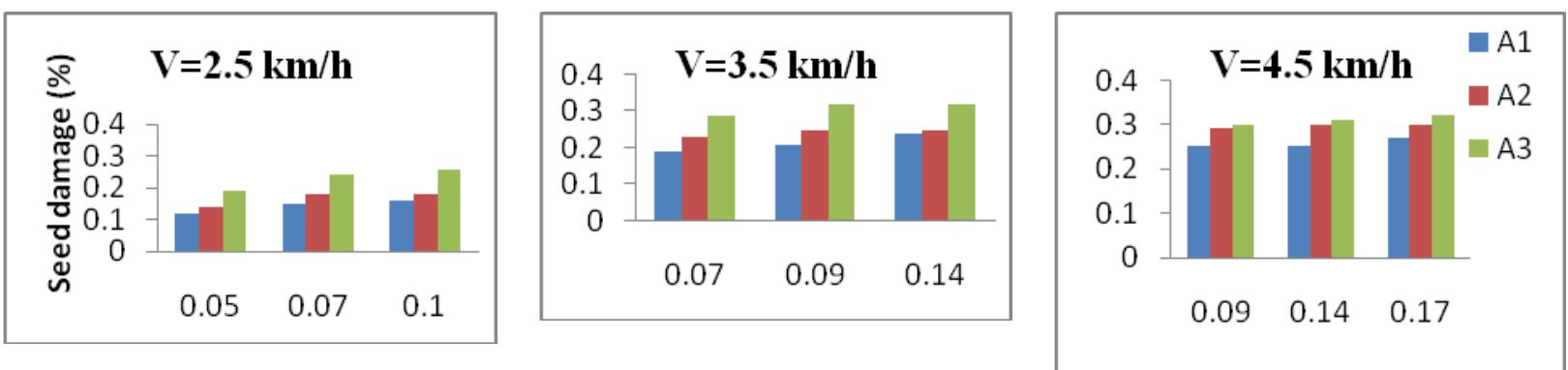

Peripheral speed of metering plate, $\mathrm{m} / \mathrm{s}$ $\mathrm{A} 1=41.01 \mathrm{~mm}^{2}, \mathrm{~A} 2=61.03 \mathrm{~mm}^{2}, \mathrm{~A} 3=77.18 \mathrm{~mm}^{2}$.

Variety-1
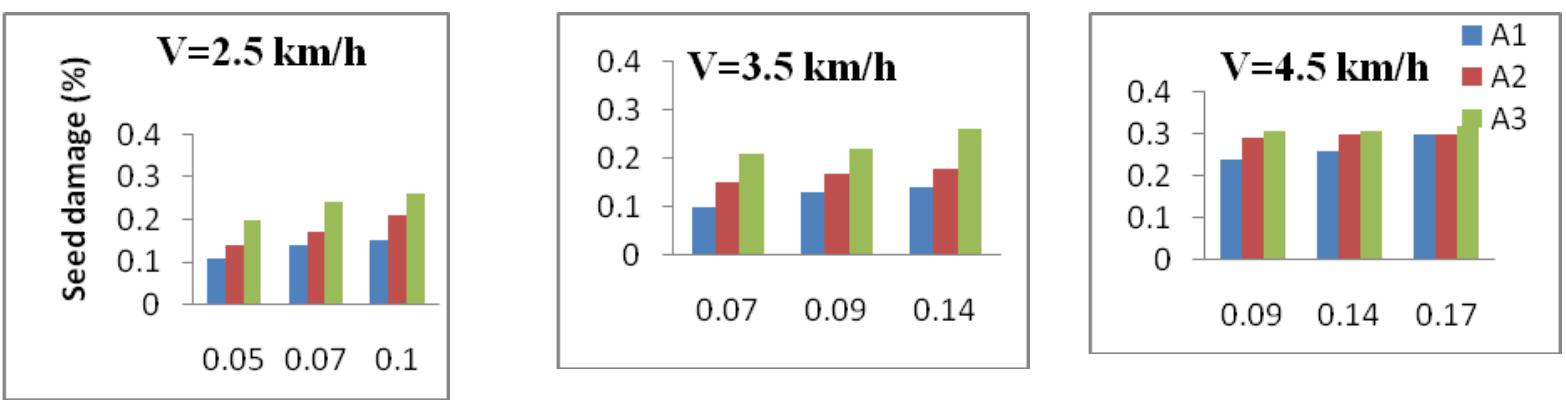

Peripheral speed of metering plate, $\mathrm{m} / \mathrm{s}$ $\mathrm{A} 1=33.67 \mathrm{~mm}^{2}, \mathrm{~A} 2=50.72 \mathrm{~mm}^{2}, \mathrm{~A} 3=64.58 \mathrm{~mm}^{2}$.

Variety-2
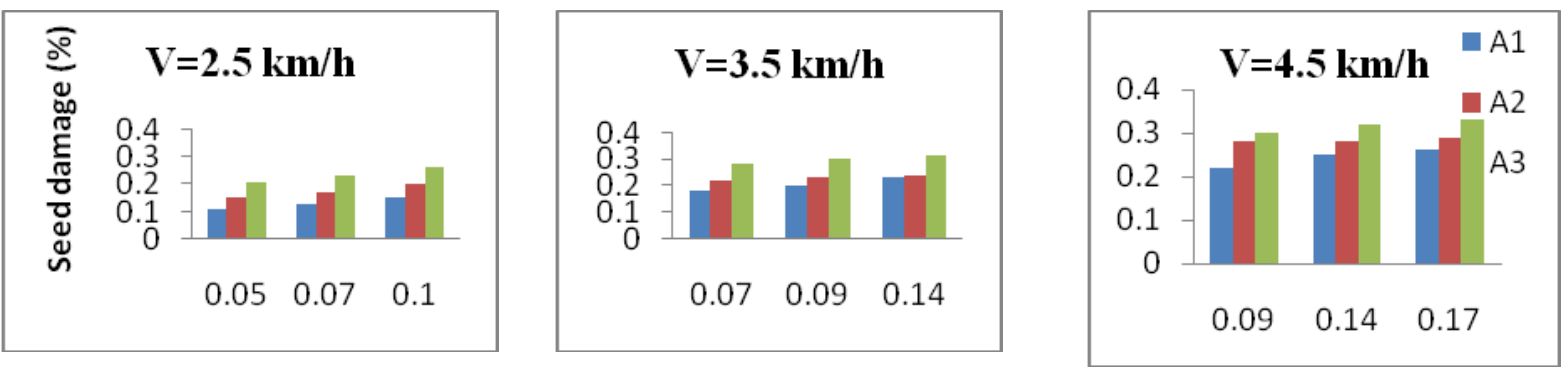

Peripheral speed of metering plate, $\mathrm{m} / \mathrm{s}$

$\mathrm{A} 1=21.08 \mathrm{~mm}^{2}, \mathrm{~A} 2=32.47 \mathrm{~mm}^{2}, \mathrm{~A} 3=41.80 \mathrm{~mm}^{2}$

Variety-3

Fig.4 Variation in percent seed damage with peripheral speed of the metering plate at various forward speed of the planting equipment for the 3 varieties. 


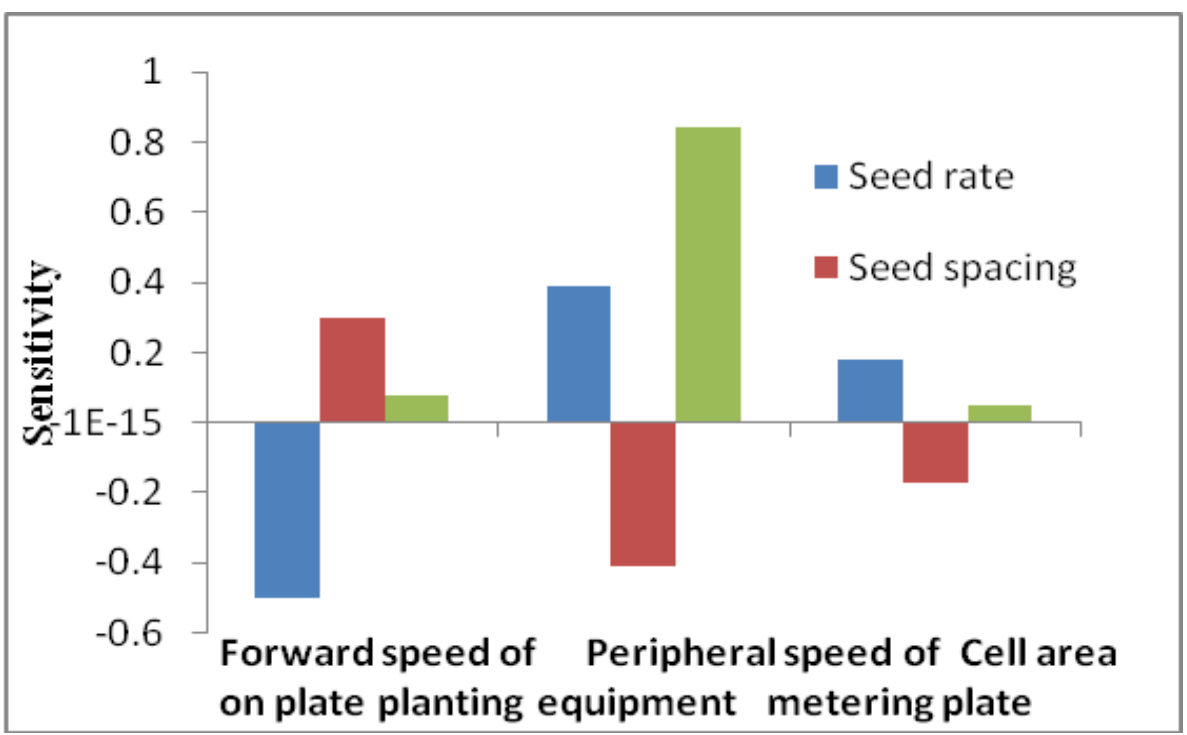

Fig.5 Sensitivity analysis of input parameters

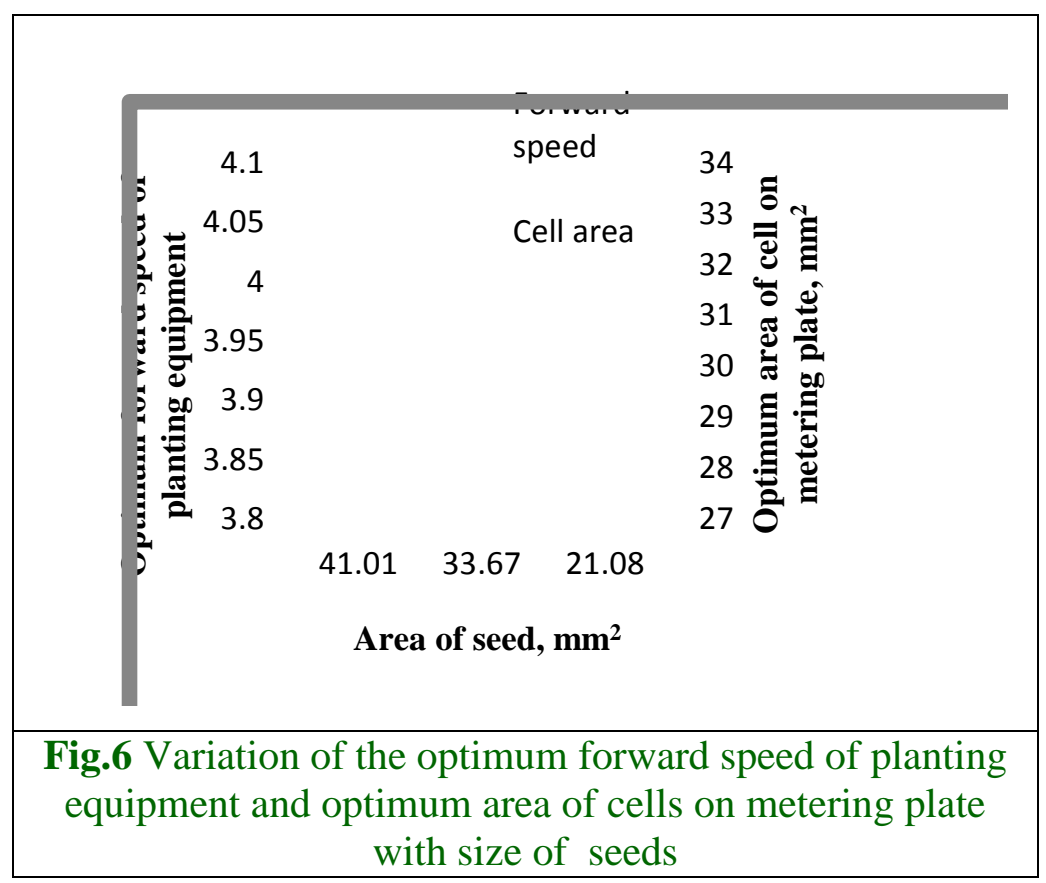


The fast time for optimization allows a number of solutions to be generated from different initial conditions for the same design goal. Considering the constraints, suitable combination of input parameters can be selected from among the generated solutions. Hence, this type of reverse mapping using the ANN model has the scope in control of operating parameters of farm machines under actual field conditions.

In conclusions, artificial neural network models were developed for the prediction of the performance parameters (seed rate, seed spacing and percent seed damage) of the inclined plate seed metering device using forward speed of the planting equipment, peripheral speed of the metering plate and area of the cells on the plate as input parameters. Three most commonly used varieties of paddy seeds were used to collect the data on the performance parameters under the laboratory conditions. Neural networks of configuration 3-4-2-3 for variety-1, 3-3-3 for variety-2 and 3-4-3 for variety- 3 were developed to model the performance parameters of the inclined plate seed metering device. The ANN model had lower mean absolute generalization error and mean percent deviation in prediction of each individual performance parameter for each variety as compared that of statistical models. ANN models predicted the performance parameters of the metering device better than that of the statistical models developed using regression analysis due to the ability of the neural network model to fully capture the input-output relationship during training of the network and its better generalization ability. The applications of neural network were extended beyond their traditional roles of black box models by applying a modified back propagation learning rule to the developed ANN models for synthesizing design and operational parameters of the metering device from desired performance parameters (reverse mapping). The optimum values of the input parameters required to obtain the seed rate of 104.68 seeds $/ \mathrm{m}^{2}$, seed spacing of $100.04 \mathrm{~mm}$ and percent seed damage of $0.19 \%$ with $100 \%$ fill of the cells were determined. The optimum peripheral speed of the metering plate was found to be $0.157 \mathrm{~m} / \mathrm{s}$ for variety- 1 and variety -2 and $0.137 \mathrm{~m} / \mathrm{s}$ for variety-3. The optimum forward speed of the planting equipment and area of cells on the metering plate had good correlation with size of seed. Linear regression equations were developed to predict the optimum forward speed of the planting equipment and area of cells on the metering plate using the size of seeds. The peripheral speed of metering plate of 0.150 $\mathrm{m} / \mathrm{s}$ can be selected for the size of seeds in the range of $29.46-32.74 \mathrm{~mm}^{2}$. The results can serve the purpose of initial approximation in the selection of design and operational parameters of the inclined plate seed metering device. But it needs to be verified under actual field conditions.

\section{References}

Al-Janobi, A.A., Aboukarima, A.M., Ahmed, K.A. 2001. Prediction of specific draft of different tillage implements using neural networks. Misr J. Agric. Eng. 18 (3), 699-714.

Bamiro, O.A, Nuradeen, A and Akuru, I.O. 1986. Introductory technology for schools and colleges. Evans brothers (Nigeria publishers) limited. Pp. 227233.

Barut, Z.B., Ozmerzi, A. 2004. Effect of different operating parameters on seed holding in the single seed metering unit of a pneumatic planter. Turk. J. Agric. For. 28, 435-441.

Benardos, P.G., Vosniakos, G.-C. 2007. Optimizing feed forward artificial neural network architecture. Eng. Appl. Artif. Intell. 20 (3): 365-382. 
Bhowmik, S. K., Sarkar, M. A. R. and Zaman, F. 2012. Effect of spacing and number of seedlings per hill on the performance of aus rice cv. NERICA 1 under dry direct seeded rice (DDSR) system of cultivation. J. Bangladesh Agril. Univ. 10(2): 191-195.

Bishop, C.M., Bamgboye, A.I and Mofolasayo, A.S. 2006. "Performance evaluation of a Two row Okra planter". Agricultural engineering international: The CIGR E journal. Manuscript pm 06002. Vol viii.

Chauhan, A.M., Dingra, H.S., Bhatia, B.S. 1999. Seed placement behavior of sunflower planter. Agric. Mech. Asia Africa Latin Am. 3 (4): 9-11.

Dash, R., Sirohi, N.P.S., 2008. A computer model to select optimum size of farm power and machinery for paddywheat crop rotation in northern India. Agric. Eng. Int. CIGR E-J. 10.

Doan, C.D., Liong, S.-Y. 2004. Generalization for multilayer neural network: Bayesian regularization or early stopping. In: Proceedings of the 2nd Conference of the Asia Pacific Association of Hydrology and Water Resources (APHW), Singapore.

Hall, J.W. 1992. Emulating Human Process Control Functions with Neural Networks. Ph. D. thesis. Dept. of Mech. Eng., Uni. of Illinois, Urbana, IL.

Hansson, P.-A. 1995. Optimization agricultural tractor cab suspension using the evolution method. Comput. Electron. Agric. 12 (1): 35-49.

Hornik, K. 1993. Some new results on neural network approximation. Neural Netw. 6 (9), 1069-1072.

Jayan, P.R., Kumar, V.J.F. 2004. Planter design in relation to the physical properties of seeds. J. Trop. Agric. 42 (1/2): 69-71.

Kachman, S.D., Smith, J.A. 1995. Alternative measures of accuracy in plant spacing for planters using single seed metering. Trans. ASAE 38 (2): 379387.

Kamble, A.K., Rahate, R.H., Devagirikar, A.A., Diwane, L.P., Alurkar, H.P. 2003. Development evaluation of multipower operational cotton planter. Bioved 14 (1/2): 29-32.

Korayem, A.Y., Younis, S.M., Hemada, A.M., 1986. Study of some factors affecting the accuracy of corn planters. Alex. J. Agric. Res. 32 (2): 27-46.

Kushwaha, R.L., Zhang, Z.X. 1998. Evaluation of factors and current approaches related to computerized design of tillage tools: a review. J. Terramech. 35 (2): 69-86.

Ma, F.-L., Li, S.-P., He, Y.-L., Liang, S., Hu, S.-S. 2006. Knowledge acquisition based on neural networks for performance evaluation of sugarcane harvester. In: Wang, J., Yi, Z., Zurada, J.M., Lu, B.-L., Yin, H. (Eds.), Advances in Neural Networks. Springer- Verlag, Berlin/Heidelberg, pp. $1270-1276$.

Mayande, V.M., Srinivas, I., Adake, R.V., Sreenivasulu, Y. 2002. Investigations on groundnut planting accuracy and seed size using inclined plate planter. Indian J. Dryland Agric. Res. Dev. 17 (2): $158-163$.

Ojha, T.P. and Micheal, A.M. 2012. Principles of Agricultural Engineering. Jain brothers East Park Road, Koral Bagh. New Delhi. Sixth Edition.

Parmer, R.S., McCledon, R.W., Potter, W.D. 1996. Farm machinery selection using simulation and genetic algorithms. Trans. ASAE 39 (5): 1905-1909.

Santos, S.R., dos Neto, P.H.W., Fey, E., Wobeto, C. 2003. Influence of soybean seed size in seeding 
processes. Rev. Bras. Eng. Agric. Ambient 7 (1): 177-181 (in Portuguese with English abstract).

Shrivastava, A.K., Jain, S.K., Dubey, A.K., Singh, V.C. 2003. Performance evaluation of tractor drawn six row inclined plate planter for oilseed and pulses. JNKVV Res. J. 37: 72-75.

Singh, R.C., Singh, G., Sarswat, D.C. 2005. Optimization of design and operational parameters of a pneumatic seed metering device for planting cotton seeds. Biosystem Engineering. 92 (4): 492-438.

Vai, M.M., Wu, S., Li, B., Prasad, S. 1998. Reverse modeling of microwave circuits with bidirectional neural network models. IEEE Trans. Microwave Theory Tech. 46 (10): 1492-1494.

Wu, S., Vai, M.M. 1997. A massively parallel reverse modeling approach for semiconductor deices and circuits. In: Proceedings of IEEE Conference on Advanced Concepts in High Speed Semiconductor Development and Circuits, Ithaca, NY, pp. 201-209.

Yazgi, A., Degirmencioglu, A. 2007. Optimization of the seed spacing uniformity performance of a vacuumtype precision seeder using response surface methodology. Biosyst. Eng. 97 (3): 347-356.

\section{How to cite this article:}

Manisha Sahu and Ajay Verma. 2018. Neural Network Prediction of Performance Parameters of an Inclined Plate Seed Metering Mechanism and its Reverse Mapping for Rice. Int.J.Curr.Microbiol.App.Sci. 7(10): 3494-3515. doi: https://doi.org/10.20546/ijcmas.2018.710.405 